\title{
NUCLEAR ENERGY IS THE ANSWER TO COPE WITH THE LACK OF ENERGY AND GLOBAL WARMING
}

\author{
WISNU ARYA WARDHANA \\ Polytechnic Institute Of Nuclear Technology \\ National Nuclear Energy Agency \\ Yogyakarta, Indonesia.
}

\begin{abstract}
NUCLEAR ENERGY IS THE ANSWER TO COPE WITH THE LACK OF ENERGY AND GLOBAL WARMING. This paper of nuclear energy is the answer to cope with the lack of energy and global warming based on the analysis of energy demand which is increasing rapidly, meanwhile the energy reserve is limited and decreased. Mostly world's energy is generated by fossil fuel energy, mainly oil and coal. Fossil fuel energy and industrial activities produce green house gases (GHG) such as : $\mathrm{COx}, \mathrm{CH}_{4}, \mathrm{~N}_{2} \mathrm{O}$, and $\mathrm{CFC}$ which cause of global warming. Global warming gives bad impact to environment and to human being. Every country in the world needs sufficient energy, but the energy resources is limited and decreased. The answer for this solution must be an energy source which doesn't produce green house gases. Why nuclear energy is chosen to cope with the lack of energy and global warming will be explained briefly in this paper.
\end{abstract}

Keywords : Global warming, nuclear energy, fossil energy, GHG.

\begin{abstract}
Abstrak
ENERGI NUKLIR ADALAH JAWABAN UNTUK MENGATASI KEKURANGAN ENERGI DAN PEMANASAN GLOBAL. Makalah energi nuklir adalah jawaban untuk mengatasi kekurangan energi dan pemanasan global ini, didasarkan pada analisis kebutuhan energi yang terus meningkat, sedangkan cadangan sumber energi terbatas dan makin sedikit. Di dunia kebanyakan energi diperoleh dari bahan bakar fosil, terutama minyak dan batubara. Pemakaian bahan bakar fosil dan kegiatan industri menghasilkan gas penyebab efek rumah kaca (COx, $\mathrm{CH}_{4}, \mathrm{~N}_{2} \mathrm{O}$ dan $\mathrm{CFC}$ ) yang menimbulkan pemanasan global. Semua negara di dunia memerlukan kepastian tersedianya energi, akan tetapi cadangan sumber daya energi terbatas dan cadangannya makin berkurang. Untuk mengatasinya harus dipilih sumber daya energi yang tidak menghasilkan gas penyebab timbulnya efek rumah kaca. Mengapa energi nuklir yang dipilih untuk mengatasi kekurangan energi dan pemanasan global, akan diuraikan secara garis basar dalam makalah ini.
\end{abstract}

Kata kunci : Pemanasan global, energi nuklir, bahan bakar fosil, efek rumah kaca 


\section{INTRODUCTION}

It is known that fossil fuel energy reserve in the world is limited and yet the energy demand is increased rapidly. This is a serious problem for every country in the world, more over for Indonesia to continue the sustainable development. In order to keep the energy demand, the energy resources in the world need to optimize the development of alternatives energy as substitute for the limit fossil fuel energy. The alternatives energy chosen should be clean and has no bad impact to environment, such as global warming. The alternative energy mainly the huge one is nuclear energy. The other alternatives energy such like renewable energy sources include geothermal, micro-hydro, solar energy, wind energy, biomass, tidal energy and fuel cell are categorized small impact to energy policy. To build a new nuclear power plant is a must to support energy demand which needed for the sustainable development.

\section{FACT AND REALITY}

It is impossible to live in modern life without sufficient energy, so the certainty of energy is a must. Man activities need energy, so every country in the world needs sufficient energy to support it's program to give the people a more prosperous life, so energy problem is the world's problem. Country which has high "Gross National Product Per Capita" (GNP), commonly also followed by high "Total Energy Per Capita" (TEC).

GNP and TEC can be used as indicator for evaluating the industrial and economy growth of any country in the world. The figure bellows showed the relation between GNP and TEC some countries ${ }^{[1]}$.

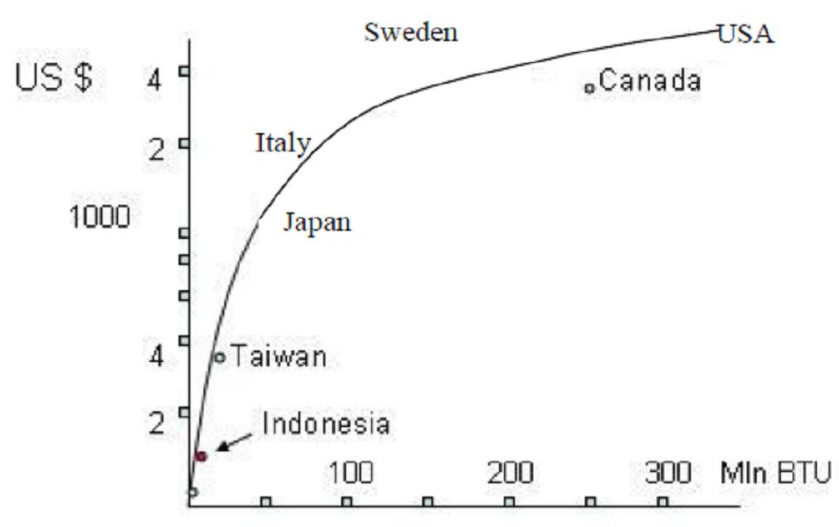

Figure 1. GNP versus TEC of Some Countries in The World 
In accordance with figure 1 above, GNP and TEC for Indonesia is low and it shows the industrial and economy growth is also low. To rise up the industrial and economy growth, Indonesia needs the certainty of energy. The production of the primair energy mostly for generating electricity, as needed for industrial activities and household electricity. The increased demand of energy, mainly for electricity has become an important problem in Indonesia, especially in accordance with the limited energy reserves. If this country doesn't apply the right management in energy policy, the lack and crisis of energy will come true.

Anticipating the lack and crisis of energy and to cope with global warming, it's time to Indonesia to choose the right energy to be developed, because the fossil energy or conventional energy reserves is limited. The reality of the limited fossil energy or conventional energy reserves in contrast of the world energy reserves as shown in Table 1.

Table 1. Fossil Energy Reserves in Indonesia in The Beginning 2000 ${ }^{[2]}$

\begin{tabular}{cccc}
\hline No. & Energy Reserves & Indonesia & $\%$, World Energy. \\
\hline 1 & Oil & 321 billion barrel & $1.20 \%$ \\
2 & Gas & 507 TSFC & $3.30 \%$ \\
3 & Coal & 50 billin ton & $3.00 \%$ \\
\hline
\end{tabular}

The energy reserves in Indonesia as the last recalculation in 2002, less than the data shown on table 1 above, what so called "the proven energy resources" as shown in Table 2.

Table 2. The Proven Energy Resources ${ }^{[3]}$

\begin{tabular}{lll}
\hline No. & Energy resources & Reserves Proven \\
\hline 1 & Oil & 5 billion barrel \\
2 & Gas & 90 TSFC \\
3 & Coal & 5 billion ton \\
\hline
\end{tabular}

When the energy production is the same with the energy production in 2002 and there is no new reserves proven, so the energy will be up in the short time, as the basic taken in year 2002 as shown in Table 3.

Table 3. The Limit Time Using Energy ${ }^{[3]}$

\begin{tabular}{ccc}
\hline No. & Energy Resources & Will be up \\
\hline 1. & Oil & 10 years. \\
2. & Gas & 30 years. \\
3. & Coal & 50 years. \\
\hline
\end{tabular}


According to table 3 above, the lack and crisis of energy will come true in a short time, so it is forced to choose the right energy to be developed immediately.

\section{PROBLEM SOLUTION}

Continuing the sustainable development in Indonesia needs the certainty of energy. To full fill the certainty of energy, Indonesia and also some ASEAN countries depend on the conventional or fossil energy. If conventional energy will be used, it must follow the requirement of the main concept for $21^{\text {st }}$ Century Energy Plants, as follows ${ }^{[4]}$ :

1. A future energy facility that would have virtually no environmental impact.

2. Conventional pollutants would be captured and either disposed of or converted to marketable co-products.

3. There would be no solid or liquid discharge.

4. Emissions of carbon dioxides and other green house gases would be reduced by ultra high efficiency technology.

5. Carbon emissions could be captured at the plant or offset by carbon removal processes applied elsewhere.

6. Plant options for new carbon dioxide emission would be available by 2015.

7. The captured carbon would be sequestrated or potentially recycled into useful products.

The main concept for $21^{\text {st }}$ Century Energy Plants above must be understood in order to avoid the global warming which cause of bad impact to environmental and human life. How can green house gases give impact to global warming, because the green house gases become gas layer covered the earth and the heat from the earth will be reflected back to earth by gases layer and the earth become warm.

Now, let's investigate what kind of wastes that will be produced by Nuclear Power Plan and Fossil Power (Coal) Plan, which generate the same electricity power, say for 1.000 MWE. The kind of wastes are as follows ${ }^{[5]}$.

Wastes of 1.000 MWE Nuclear Power Plan per year :

1. High activity waste : 27 tons

2. Medium activity waste : 310 tons

3. Low activity waste : 460 tons

4. Few waste gas of low activity through stack, but it is not excess the threshold radiation limit and safe for environment and human life. 
The all wastes are strictly collected to be processed in wastes installation and the importance things is the NPP wastes are managed well and never throw away to the environment, so the environment should be kept clean.

Wastes of 1000 MWE Coal Power Plan per year:
1. COx gas
: $6.5 \times 10^{6}$ tons
2. SOx gas
: 40.000 tons
3. NOx gas
: 22.000 tons
4. Ash / particles
: 320.000 tons (includes 400 tons of heavy metals).

Those all wastes are easily to throw away to the environment and it cause of environment pollution.

From the data given above, it is clearly to decide NPP for the best choice in generating energy without any pollution to the environment and without any impact cause of global warming. This idea to decide is also the same with the President Decree No.: 5 / 2006, which describes the development of new and renewable energy as follows ${ }^{[5]}$ :
1. Coal
$: 33 \%$
2. Gas
: $>30 \%$
3. Oil
$:<20 \%$
4. New \& Renewable Energy
$:>17 \%$
(biofuel, geothermal, nuclear, liquid coal )

$$
\text { Total } \quad: 100 \% \text {. }
$$

If nuclear energy will be chosen to cope with the lack of energy and global warming, it will give many advantages to this country. Fossil energy used will decrease and it gives great impact to Indonesia. Oil import can be controlled to minimize, it means the foreign exchange stock will grow well. Last but not least, the sustainable development can be continued smoothly and the prosperity is something found true.

If nuclear energy is obviously a part of the energy component it means Indonesia must decide to build a Nuclear Power Plan (NPP). Really, Indonesia had a plan to build NPP since 1977, but what a pity the plan had never realized yet. The problems related to the plan which never realized yet are as follows:

1. Public are still afraid to the radiation when there is a leak in nuclear reactor which caused environment damage. They also have limited information about our ability in nuclear technology more over in nuclear safety.

2. For realizing NPP needs a big investment, while the economy growth can't support yet the plan. 
3. Government has limited political will to build a NPP.

The problems as mentioned above, mostly because of the lack of understanding of the people about nuclear energy. It is easy known, because nuclear energy was understood from the $2^{\text {nd }}$ world war, where at that time Nagasaki and Hiroshima were destroyed by atomic bomb, and this atomic bombs caused many people dead by radiation. It is our responsibility to give right information to the public about nuclear energy which will give many advantages to our life ${ }^{[6,7]}$. A good public acceptance of nuclear energy must be developed. Our good experiences to operate and maintenance 3 research reactors is the answer for the question to our ability in nuclear technology. People must know that NPP has been used safely in many countries in the world as shown in the next table 4. May be this information will make a good public acceptance of nuclear energy in the future ${ }^{[8,9,10]}$.

Table 4. Total NPP in The World per April 2001 ${ }^{[3]}$

\begin{tabular}{|c|c|c|c|c|c|c|c|}
\hline \multirow{2}{*}{ No } & \multirow{2}{*}{ Country } & \multicolumn{2}{|c|}{$\begin{array}{c}\text { NPP has been } \\
\text { operated. }\end{array}$} & \multicolumn{2}{|c|}{$\begin{array}{l}\text { NPP under } \\
\text { construction }\end{array}$} & \multicolumn{2}{|c|}{$\begin{array}{l}\text { Electricity } \\
\text { supplied. }\end{array}$} \\
\hline & & $\begin{array}{l}\text { Total } \\
\text { Unit }\end{array}$ & $\begin{array}{l}\text { Capacity } \\
\text { MWE }\end{array}$ & $\begin{array}{l}\text { Total } \\
\text { Unit }\end{array}$ & $\begin{array}{l}\text { Capacity } \\
\text { MWE }\end{array}$ & $\begin{array}{l}\text { TW } \\
\text { (e)-h }\end{array}$ & $\begin{array}{c}\% \\
\text { total }\end{array}$ \\
\hline 1 & Africa (South) & 2 & 1.800 & & & 12.90 & 6.58 \\
\hline 2 & America (USA) & 104 & 97.411 & & & 753.90 & 19.83 \\
\hline 3 & Argentina & 2 & 935 & 1 & 692 & 5.73 & 7.26 \\
\hline 4 & Armenia & 1 & 376 & & & 1.84 & 33.00 \\
\hline 5 & Belgium & 7 & 5.712 & & & 45.40 & 56.75 \\
\hline 6 & Brazil & 2 & 1.855 & & & 5.55 & 1.45 \\
\hline 7 & Bulgaria & 6 & 3.538 & & & 18.18 & 45.00 \\
\hline 8 & Canada & 14 & 9.988 & & & 68.68 & 11.68 \\
\hline 9 & China & 3 & 2.167 & 8 & 6.420 & 16.00 & 1.19 \\
\hline 10 & Checkz & 5 & 2.569 & 1 & 912 & 13.59 & 18.50 \\
\hline 11 & Finland & 4 & 2.656 & & & 21.06 & 32.15 \\
\hline 12 & Hungary & 4 & 1.755 & & & 14.72 & 42.19 \\
\hline 13 & India & 14 & 2.503 & & & 14.21 & 3.14 \\
\hline 14 & England (UK) & 35 & 12.968 & & & 78.30 & 21.94 \\
\hline 15 & Iran & & & 2 & 2.111 & & \\
\hline 16 & Japan & 53 & 43.491 & 3 & & 304.87 & 33.82 \\
\hline 17 & Korea (South) & 16 & 12.990 & 4 & 3.820 & 103.50 & 40.74 \\
\hline 18 & Lithuania & 2 & 2.370 & & & 8.40 & 73.68 \\
\hline 19 & Mexico & 2 & 1.320 & & & 7.92 & 3.86 \\
\hline 20 & Netherland & 1 & 449 & & & 3.70 & 4.00 \\
\hline 21 & Pakistan & 2 & 425 & & & 1.08 & 1.65 \\
\hline 22 & France & 59 & & & & & 76.90 \\
\hline 23 & Rumania & 1 & 650 & 1 & 650 & 5.05 & 10.86 \\
\hline 24 & Rusia & 29 & 19.843 & 3 & 2.825 & 119.65 & 14.95 \\
\hline 25 & Slovakia & 6 & 2.408 & 2 & 776 & 16.49 & 53.43 \\
\hline 26 & Slovenia & 1 & 676 & & & 4.54 & 37.38 \\
\hline 27 & Spain & 9 & 7.512 & & & 59.30 & 27.63 \\
\hline
\end{tabular}


Table 4. Total NPP in The World per April 2001 ${ }^{[3]}$ (continue)

\begin{tabular}{|c|c|c|c|c|c|c|c|}
\hline \multirow{2}{*}{ No } & \multirow{2}{*}{ Country } & \multicolumn{2}{|c|}{$\begin{array}{c}\text { NPP has been } \\
\text { operated. }\end{array}$} & \multicolumn{2}{|c|}{$\begin{array}{l}\text { NPP under } \\
\text { construction }\end{array}$} & \multicolumn{2}{|c|}{$\begin{array}{l}\text { Electricity } \\
\text { supplied. }\end{array}$} \\
\hline & & $\begin{array}{l}\text { Total } \\
\text { Unit } \\
\end{array}$ & $\begin{array}{c}\text { Capacity } \\
\text { MWE }\end{array}$ & $\begin{array}{l}\text { Total } \\
\text { Unit } \\
\end{array}$ & $\begin{array}{l}\text { Capacit } \\
\text { y MWE }\end{array}$ & $\begin{array}{l}\text { TW } \\
\text { (e)-h }\end{array}$ & $\begin{array}{c}\% \\
\text { total } \\
\end{array}$ \\
\hline 28 & Sweden & 11 & 9.432 & & & 54.80 & 39.00 \\
\hline 29 & Swiss & 5 & 3.912 & & & 24.92 & 38.18 \\
\hline 30 & Ukraine & 13 & 11.207 & 4 & 3.800 & 72.40 & 47.28 \\
\hline & T O T A L & 438 & 351.327 & 31 & 27.756 & 2.447 .53 & - \\
\hline
\end{tabular}

According to the table 4, the USA is the country which has 104 NPPs, while it has many oil reserves in Mexico Gulf and in Alaska. America has a policy to keep their oil resources, so America used NPP to supply their national energy demand. America import oil and gas for domestic need from other country, mostly from Middle East countries. France is the country which has 59 NPPs the second after America, but it has the biggest electricity (70 \%) supplied by nuclear energy. Perhaps this short of information will be useful to make a good public acceptance.

Realizing NPP needs a big investment is true, but to build NPP can be done through consortium investors. It means to have NPP is something reliable and it depends on the government political will to make it possible.

To support the reasons mentioned above, it is better to explain what's about the impact of global warming to the environment and to human life. The impact of global warming such as follows ${ }^{[5]}$ :

1. The global warming impact to bio-geophysics :

a. Ice melting in north and south pole.

b. Sea level rise.

c. Desert grows larger.

d. Rain and flood over country.

e. Climate abnormally and extremely change.

f. Entirely disappeared of fauna and flora

2. The global warming impact to social welfare activities :

a. The sink down of the coastal cities

b. Infrastructures damage (road, railway, airport, harbour).

c. Crops and agricultures production damage.

d. Rising of disease and cancer risk.

\section{CONCLUSION}

1. Nuclear energy is the right answer to cope with the lack of energy and global warm, because it will give good impact to safe the limited energy 
and also to assurance the energy demand which needed for sustainable development.

2. If Indonesia can realize the nuclear energy, industries and technologies will progress and it can give a good effect to the prosperous of the people.

\section{REFERENCES}

1. RICHARD C. DORF, The Energy Fact Book, McGraw-Hill, New York,1987.

2. SOEGIANTO, "PLTN Pilihan Terakhir", Prosiding Dialog PLTN Dalam Kerangka Kebijaksanaan Energi Jangka Menengah dan Panjang, Yogyakarta, 1998.

3. WISNU ARYA WARDHANA, Dampak Pencemaran lingkungan, $4^{\text {th }}$ Edition, Yogyakara, 2004.

4. ARIONO ABDULKADIR, "Low Rank Coal Upgrading”, Majalah Energi No.12, Yogyakarta, 2001.

5. DIMAS IRAWAN, "Peran Energi Nuklir Sebagai Solusi Pemanasan Global", Workshop Iptek Nuklir Bagi Guru IPA Kab. Demak dan Kab. Boyolali, Yogyakarta, 2009.

6. RONALD ALLEN KNIEF, Nuclear Energy, McGraw-Hill, New York, 1981.

7. EL WAKIL M.M, Powerplant Technology, McGraw-Hill, New York, 1984.

8. WISNU ARYA WARDHANA, Teknologi Nuklir, Proteksi Radiasi dan Aplikasinya, Andi Offset, Yogyakarta, 2006.

9. ARIONO ABDULKADIR, "Perkembangan PLTN Saat Ini Dan Kesempatan Bagi Indonesia”, Majalah Energi No. 17, Yogyakarta, 2002.

10. WISNU ARYA WARDHANA, Al Qur'an dan Energi Nuklir, Pustaka Pelajar, Yogyakarta, 2004. 